\title{
RECONSTRUCTION OF THE DIVERSION CONCEPT IN A CHILD \\ CRIMINAL JURISDICTION SYSTEM BASED ON DIGNIFIED JUSTICE
}

\author{
I Nyoman DIPA RUDIANA (i) $1 *$ \\ I Ketut RAI SETIABUDHI (iD) 2 \\ 1 University Udayana, Faculty of Law, dipa_rudiana@yahoo.com*Correspondent Author. \\ 2 University of Udayana,, Faculty of Law, raisetiabudi_fhunud@yahoo.co.id
}

\author{
Article history: \\ Submission 02 January 2021 \\ Revision 20 February 2021 \\ Accepted 14 March 2021 \\ Available online 30 April 2021
}

\section{Keywords: \\ Diversion Concept. \\ Restorative Justice, \\ Child Protection.}

DOI:

https://doi.org/10.32936/pssi.v5i1.210

\begin{abstract}
A b s t r a c t
The renewal of the orientation of punishment for children in conflict with the law from a retributive justice approach to restorative justice is a good start for efforts to restore a victim-oriented situation by giving the perpetrator the opportunity to express his regret to the victim with the concept of diversion. However, not all cases of children are entitled to diversion. In accordance with Article 7 paragraph (2) of the SPPA Law, the requirement for diversion is a criminal act punishable by imprisonment of under 7 (seven) years and not a repetition of a criminal act. Meanwhile, criminal acts that are punishable by more than 7 (seven) years and repetition of criminal acts are not entitled to diversion. The concept of diversion and the terms of diversion are interpreted very narrowly so that they do not reflect dignified justice. The law cannot only regulate legal certainty. The law must provide a sense of justice with dignity and justice that humanize humans. This writing aims to determine the concept of diversion of the juvenile criminal justice system based on dignified justice. The type of research used is literature, the nature of this research is descriptive, the results of the research are the reconstruction of the concept of diversion based on dignified justice must be reconstructed by expanding the concept of diversion so that every child without exception has the right to get diversion.
\end{abstract}

\section{Introduction}

Children are part of citizens who must be protected because they are the generation of the nation who in the future will continue the leadership of the Indonesian nation. The general principles of child protection are non-discrimination, the best interests of the child, survival and development and respect for children's participation. Children who commit criminal acts must continue to obtain legal protection in the court proceedings in the best interest of the child both legal protection for the child perpetrator of a criminal act, the implementation of examination of the child who is the perpetrator of a criminal act, and the punishment of the child who is the criminal offender.

The Law of the Republic of Indonesia Number 11 of 2012 concerning the Juvenile criminal justice system (hereinafter abbreviated as the SPPA Law) seeks to build a system capable of providing a stronger legal basis for existing legal mechanisms by accommodating it with a mechanism in statutory provisions. This is a way out for mechanisms that have worked in society by involving law enforcers as part of the operation of this system. As a member of the United Nations, the state of Indonesia has ratified the Convention on the Rights of the Child (KHA), by issuing Presidential Decree No. 36 dated August 25, 1990, in essence declaring its commitment to respect and guarantee children's rights without discrimination in the jurisdiction of the Republic of Indonesia. On this basis, the Indonesian state is obliged to pay attention to and maintain the rights of every child to be able to grow and develop like a human being who has dignity.

The regulation of children's rights is regulated in the Universal Declaration of Human Rights (UDHR) and the International on Civil and Political Rights (ICPR), which states that children's rights are part of human rights guaranteed and protected by international law and national law. The Vienna Declaration in 
1993 at the World Conference on Human Rights (HAM) reaffirmed the principle of First Call for Children, which emphasizes the importance of national and international efforts to advance children's rights survival, development and participation (Harkrisnowo, 2002).

Protection for children in conflict with the law (hereinafter abbreviated as $\mathrm{ABH}$ ) in the juvenile criminal justice system must be interpreted broadly, not only handling children who are dealing with the law alone, but must include root causes, namely why children commit criminal acts and how prevention efforts. The scope of the juvenile criminal justice system covers many varieties and complexities, starting from the issue of children making first contact with the police, the judicial process, conditions of detention, and social reintegration, including the perpetrators in the process. The term juvenile justice system refers to the legislature, norms and standards, procedures, mechanisms and provisions, institutions and bodies that specifically deal with children who commit crimes.

The increasing level of violations committed by children that lead to criminal acts, encourages efforts to handle and handle them specifically in the field of criminal law (children) and its procedural law. This is closely related to the special treatment of juvenile offenders (Wahyono \& Rahayu, 1983). In the settlement of criminal acts, there needs to be a difference between the behavior of adults and child offenders, and if seen from the position of a child legally has not been burdened with obligations compared to adults, as long as a person is still called a child, as long as he is also not held accountable, if a problem arises against the child, efforts are made how their rights are protected law (Kusumah, 1986).

Handling of children's problems in conflict with the law to date is a serious dilemma, if the solution approach is too repressive, it will have a negative impact on the child's physical and psychological aspects. Observing the conditions of handling cases of children in conflict with the law in Indonesia so far, there has been a new breakthrough to protect children from bad impacts in resolving children's problems in conflict with the law through the SPPA Law which emphasizes solving problems with restorative justice (hereinafter referred to as justice restorative).

Restorative justice is defined as a process to involve, enable the involvement of a wider range of parties, namely those who have an interest in a specific violation. Then together, identify and direct the losses, needs, and obligations in order to heal and place the rights of the parties as possible points to be resolved. Restorative justice has fundamental characteristics with various values called inclusion (participation), democracy, responsibility, recovery, security, healing, and reintegration.
According to the United Nations Office on Drugs and Crime (UNODC), restorative justice refers to the process of solving a criminal act (crime) by focusing on repairing the victim's loss (injury), determining the perpetrator responsible for his actions, and engaging the community in resolving conflicts that occur. The process of restorative justice is any process in which victims and perpetrators or other individuals or members of the community who are affected by a crime, actively take part in solving various problems that arise as a result of the crime with the help of a facilitator. Thus, restorative justice is one way to answer the problem of criminal behavior by balancing the needs of the community, victims and perpetrators of criminal acts.

The shift in the paradigm of punishment for children in conflict with the law from a retributive justice approach to a restorative justice approach is a good start for protection efforts in the juvenile criminal justice system. The form of reform in Indonesian criminal law is the regulation of law in perspective and achievements after criminal justice events and processes known as restorative justice.

Restorative justice emphasizes justice in improving or restoring circumstances, is victim-oriented, gives the perpetrator the opportunity to express his remorse for the victim and at the same time takes responsibility for his actions, gives the perpetrator and victim the opportunity to meet to reduce hostility and hatred, restore balance in society and involve community members in recovery efforts. The aim orientation of the criminalization of restorative justice is different from retributive justice, which emphasizes justice for children's retaliation in the position of being the object and resolving unbalanced legal problems. Meanwhile, restitutive justice emphasizes justice in compensation (Rizal \& Suhariyono, 2016).

The paradigm shift from the punitive model or the restriction of freedom that has been carried out so far to a model of punishment that provides justice, especially justice directed at justice, is the starting point for the birth of the concept of restorative justice. The implementation of restorative justice against children is carried out directly against the criminal act that occurs, before the perpetrator enters the criminal justice system, where cases that enter the legal apparatus will use their discretionary rights to take diversionary actions by transferring criminal cases that occur to informal processes.

According to Article 1 point 7 of the SPPA Law stipulates that diversion is the transfer of settlement of child cases from the criminal justice process to the process outside the criminal court. The idea of diversion was proclaimed in the United Nations Standard Minimum Rules For the Administration of Juvenile 
(SMRJJ) or the Beijing Rules (United Nations General Assembly Resolution 40/33, November 29, 1985) where diversion is included in Rule 11.1., Rule 11.2., And Rule 17.4. Diversion and restorative justice are alternative forms of criminal settlement directed at informal settlement by involving all parties involved in the criminal act that occurred.

Diversion is interpreted as an effort to keep a case with certain criteria away from the formal criminal justice process towards community support to avoid negative impacts caused by the criminal justice process. The concept of diversion is in line with the non-penal justice route, namely the juvenile criminal justice model which is carried out in a non-litigation manner. The purpose of this court is to protect the interests and future of children, prioritize the principle of the best interest for the juvenile's delinquency, override the principle of ultimum remedium and are preventive in nature. In a social perspective, diversion is a constructive effort to rebuild disharmonious social relations due to criminal acts, rather than exclusion of perpetrators from the context of their social life. In the perspective of state budget allocation, detention of perpetrators of criminal acts will burden the state budget. This view is in line with the aim of diversion as stipulated in Article 6 of the SPPA Law.

Based on the legal phenomenon of children in conflict with the law that continues to develop coloring the law enforcement process, the implementation of law enforcement must be implemented directly through the implementation of diversion, namely the transfer of settlement of children's cases from criminal justice processes to processes outside of criminal justice, with the principle that the best interests of the child must be primary consideration in all countermeasures.

The form of government responsibility for this phenomenon is to form the SPPA Law as a specialist leg to replace the RI Law. No. 3 of 1997 concerning Child Court. The substance of the regulation of the SPPA Law, one of its principles, is restorative justice and diversion which aims to avoid and keep children away from the judicial process so that they can avoid stigmatization of children who are in conflict with the law and it is hoped that children can return to the social environment properly. Legal processes and imprisonment often have a destructive effect on children, ranging from the label evil or naughty that is often attached to children who are proceeding with the law, traumatic conditions, interruptions in the educational process to physical and psychological violence experienced by children.

The above explanation is used as material for legal considerations for children in conflict with the law and children as victims so that the handling of children is not aimed at retaliation and grief but as self-awareness for children so that later they can behave better. Handling of children in conflict with the law through a diversion process aims to protect and nurture children so that their future will be better and provide opportunities to grow and develop optimally with a better future.

The development of the practice of the juvenile criminal justice system that has been implemented so far as regulated in the SPPA Law is expected to fill the space of justice as the concept of restorative justice is the basic substance in the SPPA Law so that the physical and spiritual existence of children remains dignified as their human rights. Settlement of child crime in conflict with the law by using the concept of diversion through a dignified justice-based restorative justice approach.

Article 2 of the SPPA Law stipulates that the principles of SPPA are implemented based on the principles of justice, the best interests of the child, the survival and development of children, proportional, deprivation of freedom and punishment as a last resort and avoidance of retaliation. This view indicates that children are an inseparable part of human survival and the continuity of a nation and state. Therefore, children have a strategic role in which it is explicitly stated that the state guarantees every child the survival, growth and development. The logical consequence is that every settlement of a child's case must reflect a sense of justice for the child, and all decision making must always be the most basic human right for children which is protected by the state, government, society, and parents.

In reality, not all criminal acts committed by children who conflict with the law, can be carried out by diversion efforts. Normatively, Article 7 paragraph (1) of the SPPA Law stipulates that at the level of investigation, prosecution and examination of children's cases in District Courts, it is mandatory to seek diversion. Furthermore, paragraph (2) stipulates that the diversion as referred to in paragraph (1) shall be carried out in the case of a criminal act that is committed:

a. threatened with imprisonment of less than 7 (seven) years; and

b. is not a repetition of a criminal act?

If we observe the provisions of Article 7 paragraph (2) letters a and $b$, then on an contrary can be interpreted that diversion cannot be carried out in the case of a criminal offense punishable by imprisonment of more than 7 (seven) years and if it is repetition it is not criminal. When viewed from a progressive legal perspective, that law is made and applied to humans, not the other way around, namely humans for law. The existence of law is to make humans happy, the law serves the interests of humans and the rule of law is obliged to make people happy. In this context, 
diversion must be applicable in the SPPA process as long as the parties involved as stipulated in Article 8 of the SPPA Law agree to diversify so that it must be accommodated and should deliberation-based justice or justice be the highest dimension in order to resolve children's cases.

The norm of Article 7 paragraph (2) of the SPPA Law has been discriminatory by giving different treatment in terms of handling cases of children in conflict with the law. The attitude of the formation of the SPPA Law is contrary to the considerations in the SPPA Law and does not reflect the principles of the SPPA Law, namely Article 2 letter a, namely the principle of protection, letter $b$ is the principle of justice, letter $\mathrm{c}$ is the principle of nondiscrimination, letter $d$ is the best interest of the child, letter $h$ namely the principle of proportionality, letter $i$, namely the principle of deprivation of liberty is the last resort and letter $\mathrm{j}$, namely the principle of avoiding retaliation (Erwadi, 2020).

Guided by the principles of the SPPA Law as described above, diversion should not need to limit the threat of imprisonment under 7 (seven) years and not repetition of criminal acts, but diversion efforts should be implemented for all criminal acts committed by children. Legal treatment of children must not be differentiated as stipulated in Article $28 \mathrm{D}$ paragraph (1) of the 1945 Constitution of the Republic of Indonesia stipulates that every person has the right to recognition, guarantees, protection and legal certainty that is just and equal treatment before the law (Ernis, 2017).

Based on all the descriptions of the phenomena mentioned above, the writer provides a thought in the form of an idea. That an idea is an idea, a thought about a certain object or phenomenon which is used as a benchmark or point of view orientation. Ideas will guide what to aspire to, so that ideas become a means of action, and ideas will be applied because they will be useful and successful in solving problems and determining human behavior. An idea is considered correct if the idea is needed because it is to solve problems that arise in society. Thus, the idea serves to guide us to the reality. Starting from the notion of this idea, the notion of "diversion idea" is thought, the idea of diversion is used to guide in solving problems that arise in society (Wahyudi, 2007). The thinking as described above is important in the context of criminal policies regarding efforts to overcome children with problems with criminal law (perpetrators and / or victims), so it is necessary to conduct studies of statutory provisions concerning the problem of children (perpetrators and victims) currently in effect (ius constitutum) and the practice of handling child perpetrators and / or victims carried out by law enforcement officials (ius operatum) regarding the reconstruction of the concept of diversion in the juvenile criminal justice system. The results of the study of substantive, procedural and cultural provisions on the constitutum ius and operatum iur on the one hand and international instruments, the development of non-penal studies (including criminology) on the other hand, become input in the framework of the expected criminal law formation (ius constituendum).

In 2005, the National Development for Indonesian Children 2005-2015 was declared by the State Minister for Women's Empowerment. This declaration can be used as an indicator or parameter that there is a need to carry out in-depth studies of the substance, legal structure of all statutory provisions concerning Child Protection in Indonesia, primarily assessed from the compliance (consistency) of the principles, rules, and institutions regulated by laws and regulations related to Child Protection and the Convention on the Rights of the Child, especially the SPPA Law, which indicate that there are still substantive and structural weaknesses related to the concept of diversion against children in conflict with the law. Based on the above problems, the writer wants to know how the reconstruction of the concept of diversion in a juvenile justice system based dignified justice?

\section{Research Methods}

The type of research used in this research is library research or library research, which is research carried out through collecting data or scientific papers aimed at the object of research or data collection that is literature or analysis carried out to solve a problem which is basically based on research critical and in-depth towards relevant library materials. Library research or library research is a series of activities relating to methods of collecting library data, reading and taking notes and processing only library collection materials without requiring field research (Mestika, 2004).

Some of the sources used include; books, scientific journals, magazines, statistical references, newspapers, research results in theses, dissertations, internet, and other relevant sources (Samusi, 2016). Judging from its nature, this research is a descriptive study. Descriptive research focuses on systematic explanations of facts obtained when the research is conducted.

\section{Results and Discussion}

In terms of lexical and grammatical meanings, the word reconstruction has the meaning of returning to its original state or rearranging (depicting) (Mulyadi, 2020). Garner (2000) called that, "re construction is the act or process of rebuilding, recreating, or reorganizing something", so that reconstruction here is interpreted as the process of rebuilding or re-creating or reorganizing something. According to Hamzah (2010), reconstruction comes from the word reconstruction which is 
given the meaning of restructuring or rearranging and can also be given the meaning of reorganization. Zakaria (2014) in Syafiq (2014) stated that the meaning of reconstruction can be understood by renewal or re-actualization. These aspects and dimensions have three meanings, namely:

1. Reconstructing or updating with things that have been there before (reviving);

2. Reconstructing or updating something that is out of date (patchwork);

3. Reconstructing or updating with completely new forms / innovative creations.

The word reconstruction in this research is reshaping or reconstructing the concept of diversion based on the protection of children who are faced with the law in a dignified juvenile justice system.

One of the substances of the SPPA Law is the concept of diversion which is interpreted as a mechanism for the transfer of a criminal case that the law enforcement subsystem such as the police, prosecutors and judges must seek to carry out their judicial authority. In this context diversion becomes an instrument in using restorative justice as an approach in handling criminal cases, which according to Duff, as quoted by Lode Walgrave (2004), stated that restorative justice is not alternative to punishment but alternative punishment.

Restorative justice is implemented in two ways, namely the diversion mechanism and through mechanisms that work in the juvenile criminal justice system. The diversion mechanism is understood as Divertion Programme is A program that refers certain criminal defendants before trial to community programs on job training, education, and the like, which if successfully completed may lead to the dismissal of the charges (Garner, 2000).

According to Stephen VP. Grvey in Rizal and Suhariyono (2016), restorative justice as a way of responding to crime. These two views provide legitimacy that restorative justice is not just an out of court statute in handling criminal cases. Discretionary powers as a tool for diversion in the criminal justice process can be exercised by judges, prosecutors, police and correctional officers as part of their sub-system.

The terminology of children facing the law in accordance with the general provisions of Article 1 of the SPPA Law is children who are in conflict with the law, children who are victims of criminal acts, and children who are witnesses of criminal acts. Children who are in conflict with the law or in the SPPA Law use the terminology Children are children who are 12 (twelve) years old, but not yet 18 (eighteen) years old who are suspected of committing a criminal act. A child who is a victim of a crime (child victim) is a child under 18 (eighteen) years of age who has suffered physical, mental, and / or economic loss caused by the crime. Children who are witnesses of a criminal act (child witnesses) are children under the age of 18 (eighteen) who can provide information for the purposes of investigation, prosecution and examination in court about a criminal case they have heard, seen and or experienced themselves.

According to Mulyadi (2014), the SPPA Law stipulates the definition of children who are not yet 18 (eighteen) years old is still incomplete. What if the child is not yet 18 (eighteen) years old but has been married and then divorced, is it included in the category of child or is considered an adult?

First, there is the view that if the child is not yet eighteen years old but has married, it is assumed to be an adult. However, if divorced and is under 18 (eighteen) years of age, then it is again categorized as Child. Aspects and assumptions of this dimension are based on the provisions of Article 1 point (1) of Law Number 23 Year 2002 concerning Child Protection, and Article 1 point (3) of the SPPA Law. In essence, such views start from a positivistic perspective.

Second, there is the view that if so the child is still categorized as an adult. From a juridical perspective, it is impossible for a child who has been considered an adult, then retreated to be considered a child. These aspects and dimensions are based on the dimensions of civil law, the explanation of the provisions of Article 20 of the SPPA Law stipulates that children who are married and not yet 18 (eighteen) years of age are still given civil rights and obligations as adults. Hermenuetic interpretation where the provisions of various previous laws, assume the dimensions of the above context, are categorized as adults, not children anymore.

According to the author's polarization of thought, the definition of a child as regulated in the SPPA Law, which is 12 (twelve) years old, but not 18 (eighteen) years old, who is suspected of having committed a criminal act, is not yet complete. From a juridical, sociological and philosophical perspective, it is relatively more complete if the meaning is added with the sentence never married. The nature of the context of never being married is important, because if the child is not yet 18 (eighteen) years old, but has already been married, the child is not tried and does not fall under the jurisdiction of Juvenile Court anymore, but is equalized and enters the jurisdiction of justice for adults. 
In terms of the development of criminal law and the nature of modern punishment, it has introduced and developed the DoerVictims Relationship approach, which is a new approach that has replaced the deed or perpetrator approach or "daad-dader straftecht". Legal experts have introduced a formula for justice especially in the protection of human rights. Three aspects of the approach to building a legal system in the context of modernization and legal reform, namely in terms of structure, substance and culture, all of which are feasible to run integrally, simultaneously and parallel.

The relationship between diversion and restorative justice is viewed from the perspective of the SPPA as an element of the criminal justice system involved in handling cases of $\mathrm{ABH}$, the Police, the Attorney General's Office and the Court as well as Community Advisors or Correctional Centers (Bapas), Advocates or legal aid providers, Special Child Development Institutions (LPKA), Temporary Child Placement Institutions (LPAS) and Social Welfare Organizing Institutions (LPKS) as institutions or institutions that handle $\mathrm{ABH}$, starting from the child touching the justice system, determining whether the child will be released or processed in juvenile court, to the stage when the child will be placed in options ranging from being released to inclusion in the institution of punishment in the corridor of restorative justice.

The implementation of the juvenile criminal justice system in the concepts of diversion and restorative justice as described above is in line with:

1. United Nations Declaration on The Basic Principles on the Use of Restorative Justice Programs in Criminal Matters;

2. Vienna Declaration on Crime and Justice: "Meeting the challanges of the Twenty-First Century" items 2728 concerning Restorative Justice; and

3. Eleventh United Nations Congress on Crime Prevention and Criminal Justice, in point 32: Synergies and Responses: Strategis Alliances in Crime Prevention and Criminal Justice.

Punishment for juvenile offenders does not then achieve justice for the victim, on the other hand, it still leaves its own problems that are not resolved even though the perpetrator has been punished. Looking at the principles of child protection, especially the principle of prioritizing the best interests of the child, it is necessary to process the settlement of children's cases outside the criminal mechanism or commonly known as diversion. Punishment institutions are not a way to solve children's problems because they are prone to violations of children's rights.
Therefore, procedural law and procedures are needed in a system that can accommodate case settlement, one of which is by using a restorative justice approach, through a legal reform that does not only change the law but also modifies the existing criminal justice system, so that all objectives what the law intended was achieved. One form of restorative justice mechanism is dialogue among the Indonesian people, better known as musyawarah for consensus. The concept of diversion through restorative justice is a very important consideration in resolving criminal cases committed by children. If the diversion agreement is not fully implemented by the parties based on a report from the Correctional Institution (Bapas), the judge will continue the case examination in accordance with the procedural law for juvenile criminal justice. Judges in making their decision are obliged to consider the implementation of the diversion agreement.

Diversion justice is the process of solving juvenile criminal cases involving the perpetrator, the victim, the perpetrator's family / victim's family, and other related parties. Then, it is transferred to the process of resolving child criminal cases outside the criminal justice process by involving the perpetrator, the victim, the perpetrator's family, the victim's family, other related parties, community counselors, communities and professional social workers based on a restorative justice approach, to jointly overcome, resolving legal conflicts faced by children is better, providing solutions, reconciliation, reassurance or solving child criminal cases is the best interest for the children not creating retaliation that makes children stegma."

The Diversion concept, according to article 11 United Nations Standard Minimum Rules for the Administration of Dignified Justice (The Beijing Rules), It is stated that diversion is a process of transferring children in conflict with the law, from the criminal justice system to the informal justice system, such as returning to social institutions, both government (State) and non-government. This action is done to avoid negative effects on the psyche and development of children. Diversion is carried out by officers by exercising authority which is called discretion. According to article 11.1 The Beijing Rules, states that legal consideration of juvenile offenders should be given anywhere, outside of formal or juvenile justice processes that are not subject to formal court arrangements such as the District Court and the laws used are subject to the provisions of the Beijing Rules 1985, or applicable national law in Indonesia. Thus, juvenile criminal cases should not be delegated to the court, it will be more effective if using a policy or discretion in the form of a diversionary court with other sanctions."

According to the author, juvenile justice in accordance with the explanation above is a diversion court model by reconciling the principle of equality before the law with the Family Group 
Conferencing model from Wundersitz, the principle of ultimum remedium, Law of the Republic of Indonesia No. 35 of 2014 concerning Child Protection, UU SPPA. By comparing the rules of The Beijing Rules General Assembly Resolution 40/33 of 29 November 1985, the Child Protection Act in South Australia which emphasizes the protection of victims and perpetrators of child crimes (The Children's Protection and Young Offender Act 1979) and the Criminal Law Children in New South Wales (The Children's Criminal Protection Act 1987, of which article 56 a, stipulates that Children have right and freedom before the law equal to those enjoyed by adults and in the process. Article 56 a The Children's Criminal Protection Act of New South Wales says all children have the same rights and freedoms before the law as adults have.

The principle of equality before the law for children's cases must be implemented in a diversion justice model. If the wishes of the community do not want the punishment of children to be imposed, then the punishment cannot be (given) to the child. Crime cannot be applied if there are other solutions that are beneficial for the child, for example, diversion solutions. The diversion justice model is intended to avoid the stigma that children are considered to have committed a criminal act. The term crime is not appropriate to apply to children who are in conflict with the law. Children should not be subject to maximum punishment because in essence children in conflict with the law are victims, victims of broken home from their families, victims of social conditions, victims of economic conditions, victims of educational and cultural conditions, or victims of acts of violence from the surrounding environment. In essence, the child is also a victim of culture, victims of economic neglect, victims of education, victims of injustice, victims of social exploitation and victims of policies in a country.

If diversion efforts have been carried out but are unsuccessful, then the juvenile criminal justice model in conflict with the law can be resolved through the penal court. Penal justice channel means that the judicial process is completed formally or penal court in court. The process of juvenile justice in court is based on the SPPA Law. According to Hadisupraptop (2006), the prevention of dignified delingquency is part of the criminal policy which in its operational motion can use 2 (two) routes, namely: (a). criminal policy, the penal line is more repressive, and (b). nonpenal criminal policy, which focuses more on preventive properties. In line with this criminal policy, Achmad Ubbe (2013) cited Barda Nawawi Arief's opinion in the Explanatory Memorandum and Recommendation of the European Council No. R (99) 19 regarding Mediation in Penal Matters, penal mediation can be done with a model:
1) Informal "Mediation"

2) Traditional "or Tribal Moots"

3) Victim-Offenders Mediation

4) Reparation "Negotiation Programs"

5) Community "Panels or Courts"

6) Family and Community Group Conferences.

The juvenile criminal justice process through the penal route is a juvenile justice process that is specific in nature, meaning that the quality of cases, delinquency or crimes committed by children is already a crime that attracts public attention, the modus operandi that is carried out is more professional, carried out by mens rea criminal are concerned about public interests and security, for example narcotics trafficking, involvement in criminal acts of terrorism, committing premeditated murder".

Two years after the SPPA Law was enacted on August 1, 2014, the Indonesian Supreme Court responded to the SPPA Law progressively by establishing the Supreme Court Regulation of the Republic of Indonesia Number 4 of 2014 concerning Guidelines for the Implementation of Diversion in the Juvenile Criminal Justice System (abbreviated as Perma No.4 of 2014). The Perma even took effect before the formation of a Government Regulation which is a derivative of the SPPA Law. Provisions of Article 3 of Perma No. 4 of 2014, stipulates that juvenile judges are obliged to seek diversion in the event that a child is charged with committing a criminal offense punishable by imprisonment of less than 7 (seven) years and also charged with a crime punishable by imprisonment of more than 7 (seven) years in the form of a subsider indictment alternative, cumulative or combination.

Establishment of Perma No. 4 of 2014 shows that the Supreme Court of the Republic of Indonesia has acted progressively by accommodating, expanding and flexing the provisions of diversion. Normatively, the scope of implementation of diversion is regulated in Article 7 paragraph (2) of the SPPA Law, where Article 7 paragraph (2) letters a and b of the SPPA Law is on an contrary interpreted to mean that it is impossible to carry out diversion against criminal acts punishable by imprisonment of more than 7 (seven) years and commits a criminal act repeated. However, the next problem is what if the child who is suspected or charged with a single count is threatened with imprisonment of more than 7 (seven) years, is it still possible to do diversion?

The idea of expanding the implementation of the diversion concept in accordance with the provisions of Article 7 paragraph (2) of the SPPA Law will be reviewed on the basis of the theory of dignified justice initiated by Teguh Prasetyo (2015) hereinafter called dignified justice. The concept of diversion will later be 
used not only in solving cases of children who are threatened with imprisonment of less than 7 (seven) years and are not a repetition of a criminal act, but can also be applied to cases of children who are threatened with imprisonment of more than 7 (seven) years. The benefits behind such an idea include reducing the level of conflict in law enforcement in the community according to the diversion objectives in the SPPA Law.

Dignified justice departs from the basic premise that has the aim that law can provide a sense of justice that is dignified and justice that can humanize humans. Dignified justice delves into law from the layers of legal science including legal philosophy, legal theory, legal dogmatic and the last law and legal practice. The character of justice is dignified, namely directing all rules and principles (material legal discipline), including the value of the network of rules and principles in which there are virtues (policies) that bind one another".

The structure of the relationship between principles and values makes justice with dignity a strong foundation of knowledge in building just law because the spirit of the living law comes from Indonesian law, namely Pancasila (Volksgeist) (Prasetyo, 2015). The emphasis is placed on the principles of just and civilized humanity, which underlies the humanizing conception of humans. Dignified justice also explains the purpose of law in terms of justice, certainty and benefit that exist in each legal principle and rule that are interrelated with one another in the system. Dignified justice is of the opinion that the benefit and legal certainty is an integral part of justice.

Dignified justice can be interpreted that punishment or punishment is still carried out (for the sake of legal certainty) but the spirit of humanizing humans should not be ignored but still upheld. Provided by a legal system with spiritual and material dimensions, based on the values of Pancasila especially the second principle, namely the principle of humanity that is just and civilized and is imbued with the first principle of God Almighty. The concept of diversion must provide dignified justice and respond to conditions that exist in society. The law must not make itself as a person who only regulates legal certainty. Therefore, the law must be able to harmonize, balance the existing needs in the context of legal flexibility, regulate human behavior, because these laws exist to regulate society and not society for laws.

The meaning of humanizing a human being in the concept of diversion based on dignified justice is that even though the child is alleged to be guilty according to the law of committing a criminal act which is punishable by more than 7 (seven) years and committing a repeat offense, the child must still be treated as a human being in accordance with the rights of the child attached to him, then justice with dignity becomes justice that balances rights and obligations.

Based on the explanation above, the author is of the opinion that diversion efforts can be carried out against all criminal acts as long as the parties want and are involved in diversion, in this case the victim and / or his family according to the provisions of Article 8 of the SPPA Law agree to diversion so that such a desire must be accommodated with a justice approach. dignified justicebased restorative which is the highest dimension in order to resolve children's cases. Thus, diversion attempts for children who are subject to imprisonment for more than 7 (seven) years and committing repetition of a criminal act are obligatory under the law to undertake diversion efforts with the aim of protecting the interests and future of the child, both as the perpetrator and as the victim of a criminal act.

\section{Conclusions}

The concept of the diversion of the Juvenile Criminal Justice System Law is interpreted very narrowly. Not all children who are in conflict with the law are entitled to diversion. In accordance with Article 7 paragraph (2) of the SPPA Law, the requirement for diversion is a criminal act punishable by imprisonment of under 7 (seven) years and not a repetition of a criminal act. Meanwhile, criminal acts that are punishable by more than 7 (seven) years and repetition of criminal acts are not entitled to diversion so that the concept of diversion does not reflect dignified justice because the law cannot only regulate legal certainty. The law must provide a sense of justice with dignity and justice that humanize humans. The reconstruction of the concept of diversion of the child criminal justice system based on dignified justice must be built by expanding the concept of diversion so that every child, without exception, who commits a criminal act is entitled to diversion.

So that the national authorities, namely the legislature and the executive, take strategic steps, namely revising the SPPA Law and its derivative regulations by expanding the concept of diversion and reformulating the concept of diversion which is based on the protection of children in conflict with the law in a dignified justice-based juvenile justice system.

\section{References}

1. Ernis, Y. (2017). Diversi Dan Keadilan Restoratif Dalam Penyelesaian Perkara Tindak Pidana Anak Di Indonesia (Diversion and Restorative Justice in Case Settlement of Juvenile Justice System in Indonesia). Jurnal Ilmiah Kebijakan Hukum, 10(2), 163-174. http://dx.doi.org/10.30641/kebijakan.2016.V10.163174 
2. Erwandi, E. (2020). PK Bapas dalam Penyelesaian Anak yang Berkonflik dengan Hukum Sesuai Amanat UU SPPA. Jurnal Pemikiran Dan Pengembangan Pembelajaran, 2(2), 35-40. Retrieved from http://ejournaljp3.com/index.php/Pendidikan/article/view/103

3. Hadisuprapto, P. (2006). Peradilan Restoratif Model Peradilan Anak Indonesia Masa Datang, Inauguration Speech of Professor in the Field of Criminology at the Faculty of Law, Semarang, Diponegoro University, February 18, 2006.

4. Hamzah, A. (2010). Asas-asas hukum pidana di Indonesia \& perkembangannya. Jakarta, Rineka Cipta.

5. Harkrisnowo, H. (2002). Tantangan dan Agenda Hak-Hak Anak. Edisi Februari. Jakarta, Newsletter Komisi Hukum Nasional.

6. Kusumah, M.W. (1986). Hukum dan Hak-hak Anak. Jakarta, CV. Rajawali.

7. Mestika, Z. (2004). Metode Penelitian Kepustakaan. Jakarta, Yayasan Bogor Indonesia.

8. Mulyadi, L. (2014). Wajah Sistem Peradilan Pidana Anak Indonesia. Bandung, Alumni.

9. . (2020). Model Ideal Pengembalian Aset (Asset Recovery) Pelaku Tindak Pidana Korupsi. Jakarta, Kencana.

10. Prasetyo, T. (2015). Keadilan Bermartabat Prespektif Teori Hukum. Bandung, Penerbit Nusa Media.

11. Rizal, J. and Suhariyono AR. (2016). Demi Keadilan Antologi Hukum Pidana dan Sistem Peradilan Pidana. Jakarta, Pustaka Kemang.

12. Sanusi, A. (2016). Metodologi Penelitian Bisnis. Jakarta, Salemba Empat. Avaliable at: https://openlibrary.telkomuniversity.ac.id/pustaka/14 997/metodologi-penelitian-bisnis.html

13. Syafiq, A. (2014). Rekonstruksi Pemidanaan Dalam Hukum Pidana Islam (Perspektif Filsafat Hukum). Legal Reform Journal, 1(2), p. 157-199. http://dx.doi.org/10.26532/jph.v1i2.1484

14. Ubbe, A. (2013). Mediasi Penal dan Peradilan Adat. Paper presented at the Seminar on Adat Justice in the National Legal System. Surabaya, the National Law Development Agency, Ministry of Law and Human Rights.

15. United Nations Office on Drugs and Crime (UNODC). (2006). Handbook on Restorative Justice Programme. Criminal Justice Handbook Series. Available at: https://www.unodc.org/pdf/criminal justice/Handbo ok on Restorative Justice Programmes.pdf
16. Walgrave, L. (2004). Restoration in Youth Justice. Chicago, University of Chicago.

17. Wahyono, A. \& Rahayu, S. (1983). Tinjauan Peradilan Anak di Indonesia. Jakarta, Sinar Grafika.

18. Wahyudi, I. (2007). Pengantar Epistemologi. Yogyakarta, Badan Penerbit Filsafat UGM, LIMA. 